\title{
PROTECTIVE EFFECT OF ELLAGIC ACID IN VASCULAR EPOXIDATION DAMAGE IN A MURINE MODEL OF ATHEROSCLEROSIS
}

\author{
YANHUA XIONG $^{1},{\text { WENPING } Z^{2} \mathrm{XNG}^{2}}^{2}$ \\ ${ }^{I}$ Internal Medicine of Traditional Chinese Medicine, Zhejiang Hospital, Hangzhou, 310007, China \\ ${ }^{2}$ Department of Cardiology, Zhejiang Hospital, Hangzhou, 310007, China \\ *corresponding author: zengwenping2125@163.com
}

Manuscript received: December 2018

\begin{abstract}
In order to explore the mechanism underlying the protective effect of ellagic acid (EA) against vascular dysfunction and oxidative damage in vascular endothelial cells, a high-fat diet (HFD) murine model was established using $32 \mathrm{ApoE}^{-/-} \mathrm{mice}^{\mathrm{c}}$ and 32 wild type C57BL/6 mice (WT). The degree of atherosclerosis, blood biochemical parameters, the expression of nitric oxide synthase (NOS), the expression of Nrf2 (nuclear factor (erythroid derived 2) like 2) and HO-1 (heme oxygenase-1) proteins were analysed. In addition, the protective effect of EA against oxidative damage in mouse vascular endothelia was studied by detecting the relaxation status of vascular endothelia. The results showed that the plaque area of atherosclerosis decreased significantly in mice treated with EA by increasing the expression of Nrf2 and HO-1 in blood vessels. The level of $\mathrm{Nrf} 2$ and HO-1 proteins in the arteries of WT mice and $\mathrm{ApoE}^{-/-}$mice treated with EA were significantly increased, suggesting that EA improves vasodilation by increasing Nrf2 expression.
\end{abstract}

\section{Rezumat}

Pentru a studia mecanismul care stă la baza efectului protector al acidului ellagic (EA) asupra disfuncției vasculare şi a leziunii oxidative în celulele endoteliale vasculare, a fost utilizat un model murin cu dietă bogată în grăsimi (HFD) folosind 32 de şoareci $\mathrm{ApoE}^{-/-}$şi 32 de şoareci tip C57BL/6 (WT). A fost analizat gradul de ateroscleroză, parametrii biochimici, expresia nitric oxid sintazei (NOS), expresia Nrf2 (factorul nuclear 2) și HO-1 (hem oxigenază-1). În plus, efectul protector al EA împotriva degradării oxidative în endoteliul vascular a fost studiat prin detectarea stării de relaxare a acestuia. Rezultatele au arătat că zona plăcii de ateroscleroză a scăzut semnificativ la șoarecii tratați cu EA prin creșterea expresiei Nrf2 şi HO-1 în vasele de sânge. Nivelul proteinelor Nrf2 şi HO-1 din arterele şoarecilor WT şi ApoE ${ }^{-/-}$trataţi cu EA a fost semnificativ crescut, sugerând că EA îmbunătățește vasodilatația prin creșterea expresiei Nrf2.

Keywords: ellagic acid, vascular epoxidation damage, Nrf2 protein, HO-1 protein

\section{Introduction}

Vasodilation and contraction are maintained by vascular endothelial cells, whose damage is the pathological basis of atherosclerosis. Contractile and diastolic factors synthesized and secreted by vascular endothelial cells can maintain vasoconstrictive functions [1,2]. As an early symptom of atherosclerosis, endothelial cell injury induces the generation of pathological stress and impairs normal vasomotor functions [3]. Endothelial damage and oxidative stress are implicated in the pathogenesis of atherosclerosis [4]. Polyphenolic natural compounds were extensively studied for their antioxidant, antitumoural and protective effects in many chronic diseases $[5,6]$.

As a polyphenolic compound, ellagic acid (EA) is a polyphenolic compound that can be found in all kinds of soft fruits and nuts, raspberries, blueberries, walnuts and Chinese herbal medicines such as Paeonia lactiflora and gallnut. Studies showed that EA has a significant inhibitory effect on carcinogenesis induced by chemical substances [7], being able to prevent macrophage peroxidation to a certain degree. According to previous studies, EA exerts significant effects on the treatment of blood dysfunction and stasis via the $\mathrm{Nrf} 2$ pathway, which is involved in the maintenance of vascular anti-diastolic functions by regulating the balance of oxides and antioxidants [8]. The presence of both Nrf2 and HO-1 in blood vessels can activate antioxidant enzymes to achieve a balance in the regulation of oxidative stress. In the treatment of oxidative damage of vascular endothelial cells it was showed that the uptake of polyphenols could activate Nrf2 and start the antioxidant cascade [11]. However, the antioxidant effect of EA in the process of atherosclerosis remains unclear. It is speculated that EA can improve atherosclerosis in the long run and it has a certain mitigation effect on oxidative damage of blood vessels.

The current study aimed to investigate the mechanism underlying the protective effect of EA against vascular 
dysfunction and oxidative damage in vascular endothelial cells using a high-fat diet (HFD) murine model.

\section{Materials and Methods}

Animals

$32 \mathrm{ApoE}^{-/-}$mice, $8 \mathrm{Nrf2}^{-/-}$mice aged 6 - 8 weeks and 32 wild type $\mathrm{C} 57 \mathrm{BL} / 6$ mice (WT) with the same genetic background were selected for this study. The animals were purchased from Nanjing Junke Bioengineering Co., Ltd., China. The animals were acclimatized to the new laboratory conditions for 7 days before the study begin. During the acclimatization period and during all the period of the experiments began the animals were housed in standard conditions with a temperature of $19^{\circ} \mathrm{C}-26^{\circ} \mathrm{C}$, of $52 \%-63 \%$ humidity and light $12 \mathrm{~h} /$ day. This study has been approved by the Ethics Committee of Zhejiang Hospital, China and all the animal were in accordance with the international regulations in force regarding animal studies (American Veterinary Medical Association).

The 72 mice were randomly divided into six groups as follows: WT-HFD group (16 mice), WT-HFD + EA group (16 mice), ApoE ${ }^{-/}$-HFD group (16 mice), $\mathrm{ApoE}^{-/}$HFD + EA group (16 mice), $\mathrm{Nrf} 2^{-/}$-HFD group (4 mice) and $\mathrm{Nrf}^{-/-}$-HFD+EA group (4 mice). The mice from WT-HDF, ApoE ${ }^{-/}$-HFD and $\mathrm{Nrf}^{-/}{ }^{-}$-HFD groups were fed with $30 \mathrm{mg} / \mathrm{kg} /$ day high-fat diet $(21 \%$ fat content, $0.2 \%$ cholesterol content), while the mice from WT-HFD + EA, ApoE ${ }^{-/}$-HFD + EA, Nrf2 ${ }^{-/}$-HFD groups were fed with a $30 \mathrm{mg} / \mathrm{kg} /$ day HFD diet plus $0.5 \mathrm{~g} / \mathrm{kg} /$ day EA for 14 weeks. $\mathrm{Nrf2}^{-/}$groups were only used for detection of the effect of $\mathrm{HOCl}$ on vascular diastolic response.

\section{Analysis of the degree of atherosclerosis}

Except for Nrf2-/-mice, 4 mice from each of the four groups were sacrificed by cervical dislocation at the end of the experiment and the upper thoracic aorta was collected and divided in two parts: one for histopathologic examination and the other part was freezed at $-80^{\circ} \mathrm{C}$ for Western Blot analysis. Histopathological examinations were carried out by immobilizing blood vessel samples in a polyformaldehyde solution (Xi'an Reagent Factory, China), followed by dehydration with a sucrose solution and embedding using a paraffin embedding machine (Leica, Germany). After being washed in running tap water for more than $1 \mathrm{~h}$, the samples were dehydrated for 10 minutes using gradient ethanol $(50 \%, 70 \%$, $80 \%, 90 \%$ and $100 \%$, respectively). Then, the specimens were treated twice with $100 \%$ toluene for $10 \mathrm{~min}$ each time, and soaked in different wax cylinders at $60^{\circ} \mathrm{C}-65^{\circ} \mathrm{C}$ for $2 \mathrm{~h}$. Finally, the samples were sliced using a paraffin microtome (Leica, Germany) and stained with hematoxylin-eosin using the standard procedure [9]. The slices were then analysed and the images were processed using ImagePro Plus 5.0 software.
Biochemical analysis

After $16 \mathrm{~h}$ of fasting, except for Nrf2-/-mice, other 4 mice in each group were anesthetized (ketamine $3.1 \mathrm{mg} / 100 \mathrm{~g}$ ) for blood sample collection. The blood samples were centrifuged (3000 rpm, $15 \mathrm{~min}$ ), the serum was collected and stored at $-80^{\circ} \mathrm{C}$ for later use. The total serum cholesterol (TC) and triglycerides (TG) were measured using an automatic biochemical analyser (Hitachi, Japan) based on the instructions of the manufacturer. Enzyme-linked immunosorbent assay (ELISA) was used to detect serum antioxidant markers and adhesion factors. The serum levels of sICAM-1 (soluble inter-cellular adhesion factor-1) and sP-selectin (soluble P-selectin) were measured by an ELISA kit (Shanghai Transhold Navigation Tech., China) in accordance with the kit instructions. The absorbance value was read at $450 \mathrm{~nm}$ on a plate reader. The serum concentrations of SICAM-1 and sP-selection were calculated based on standard curves. The antioxidant activity was evaluated by measuring the ferric reducing ability of plasma (FRAP) (ferric ion reducing antioxidant power) [11]. The results were expressed as $\mu \mathrm{mol} \mathrm{Fe} / \mathrm{mL}$.

Nitric oxide synthase (NOS) activity

The artery tissues of mice were taken from a $-80^{\circ} \mathrm{C}$ freezer and mixed with $1.0 \mathrm{~mL}$ of a pre-cooled homogenate medium (Normal saline) before the sample tissues were homogenated in a glass homogenizer. Next, the supernatant was collected by centrifugation (3000 rpm, $15 \mathrm{~min}$ ) and the activity of NOS in the supernatant was determined by an ELISA NOS kit in strict accordance with kit instructions.

\section{Western Blotting}

The expression of HO-1 and Nrf2 in the thoracic aorta of mice in each group was determined by Western Blot. Preparation of vascular tissue homogenate: 50 $\mathrm{mg}$ of fresh arterial plaque tissues were homogenated (50 $\mathrm{mg}$ fresh arterial plaque tissue was shredded). Then, $600 \mu \mathrm{L}$ of a Western lysate (Dingguo Changsheng Biological Company, China). Subsequently, $1 \mu \mathrm{M}$ of PMSF (phenylmethylsulfonyl fluoride) was added and the homogenate was incubated on ice for $30 \mathrm{~min}$ before being subjected to centrifugation $\left(4^{\circ} \mathrm{C}, 12000\right.$ $\mathrm{rpm}, 5 \mathrm{~min}$ ). The cells were immediately treated with glucose and RSG (rosiglitazone) for protein imprinting. A certain amount of protein samples were mixed with the same amount of a sample buffer (Cell Signaling Technology, USA) and boiled. After centrifugation (10000 rpm, $10 \mathrm{~min}$ ), the supernatant was taken and aliquoted. SDS-PAGE electrophoresis was performed to separate the protein (Kangwei Century Biotechnology Company, China), which was then transferred onto a NC membrane (Sigma, USA) using a semi-dry rotation device. Afterwards, the NC membrane was blocked by $8 \%$ skimmed milk powder at room temperature for $1 \mathrm{~h}$. The protein was transferred to NC membranes (Sigma USA) using a semi-dry rotation device. At room temperature, $8 \%$ skimmed milk powder was 
enclosed for 1 hour, then incubated at 4 degrees Celsius in the first antibiotic solution, and then incubated at $4{ }^{\circ} \mathrm{C}$ with primary anti-fat antibodies; the membrane was washed 4 times with TBST ( $15 \mathrm{~min} / \mathrm{each})$. Then, the membrane was incubated with HRP II antibody (dissolved in TBST) at $37^{\circ} \mathrm{C}$ for $30 \mathrm{~min}$. The electrophoretic bands were then analysed by an automatic gel imaging system (Syngene Company, Britain).

Preparation of in vitro vascular rings

4 mice from each group and all $\mathrm{Nrf}^{-/-}$mice were sacrificed, their thoracic aortas were quickly removed and put into a $\mathrm{K}-\mathrm{H}$ buffer solution $(\mathrm{NaCl} 118.3$ $\mathrm{mmol} / \mathrm{L}, \mathrm{KCl} 4.7 \mathrm{mmol} / \mathrm{L}, \mathrm{MgSO}_{4} 7 \mathrm{H}_{2} \mathrm{O} 1.2 \mathrm{mmol} / \mathrm{L}$, $\mathrm{KH}_{2} \mathrm{PO}_{4} 1.2 \mathrm{mmol} / \mathrm{L}, \mathrm{CaCl}_{2} 2.5 \mathrm{mmol} / \mathrm{L}, \mathrm{NaHCO}_{3}$ $24.0 \mathrm{mmol} / \mathrm{L}$, EDTA $0.03 \mathrm{mmol} / \mathrm{L}$, and $\mathrm{pH} \mathrm{7.4),}$ followed by gas $\left(95 \% \mathrm{O}_{2}+5 \% \mathrm{CO}_{2}\right)$ injection into the buffer solution. The connective tissues and fat were stripped off before the blood vessels were cut into $4 \mathrm{~mm}$ rings. Finally, the vessel rings were transferred into a bath containing a $\mathrm{K}-\mathrm{H}$ buffer in an atmosphere of $95 \% \mathrm{O}_{2}+5 \% \mathrm{CO}_{2}$ (AS-2, USA). Detection of diastolic function of vascular endothelium The vessel rings were placed in the bath system while one end of the vessel was connected to a tension transducer (Leica, Germany). Systolic and diastolic data of vascular ring samples were collected after the vessels were balanced for $90 \mathrm{~min}$ under $2 \mathrm{~g}$ of resting tension. $1 \mu \mathrm{mol} / \mathrm{L}$ phenylephrine (Phe) was added on each vascular ring to induce constriction. Then, an accumulated concentration of acetylcholine (Ach) $\left(1 \times 10^{-10}-1 \times 10^{-5} \mathrm{~mol} / \mathrm{L}\right)$ relaxed the rings after the contractile response of the rings reached a plateau.

Measurement of the diastolic percentage: Ach and papaverine $(0.3 \mu \mathrm{mol} / \mathrm{L})$ were used to relax the vascular rings, respectively, before the diastolic percentage of the vascular rings was obtained. $\mathrm{HOCl}$ pre-treatment was carried out to induce oxidative damage. The protective effect of EA on the tension of vascular rings induced by oxidative damage was then observed. After the rings were rinsed with a fresh Kerb's solution (in-house prepared) for several times, the muscle trough was cleaned and the tension was restored to the baseline. The ring was then stabilized for about 10 min under $2 \mathrm{~g}$ of tension. Phe $\left(1 \times 10^{-6} \mathrm{~mol} / \mathrm{L}\right)$ was used to constrict blood vessels. The endotheliumdependent and non-endothelium-dependent relaxation responses induced by an accumulative concentration of Ach $\left(1 \times 10^{-10}-1 \times 10^{-5} \mathrm{~mol} / \mathrm{L}\right)$ were then recorded and analysed.

Detection of the effect of $\mathrm{HOCl}$ on vascular diastolic function

Because $\mathrm{HOCl}$ can cause oxidative damage to the blood vessels of mice, some of the blood vessels of mice were pre-treated with $\mathrm{HOCl}$. The vasodilatation of the blood vessels of mice treated with $\mathrm{HOCl}$ was compared with that of mice treated with or without EA, in order to determine whether EA can alleviate the oxidative damage of blood vessels.
The diastolic experiment of vascular rings from WT mice in HFD group: HFD; HFD + EA treatment group (EA treatment for 6 hours); HFD + $\mathrm{HOCl}$ treatment group ( $\mathrm{HOCl}$ intervention for $100 \mu \mathrm{M}$ culture for one hour to cause oxidative damage). In high fat diet + $\mathrm{HOCl}$ treatment + ellagic acid treatment group, $\mathrm{HOCl}$ intervention was first used to cause oxidative damage, and then cultured with ellagic acid treatment for 6 hours.

The diastolic experiment of $\mathrm{ApoE}^{-/-}$mice in HFD group: HFD group; HFD group + EA treatment group (EA treatment for $10 \mu \mathrm{M}$ culture for 6 hours); HFD group $+\mathrm{HOCl}$ treatment group $(\mathrm{HOCl}$ intervention for $100 \mu \mathrm{M}$ culture for one hour to cause oxidative damage). In the high fat diet $+\mathrm{HOCl}$ treatment + ellagic acid treatment group, $\mathrm{HOCl}$ was first used to cause oxidative damage, and then cultured for 6 hours with ellagic acid treatment.

The diastolic experiment of vascular rings from $\mathrm{Nrf}^{-/-}$mice in HFD group: HFD group; HFD + EA treatment group (EA treatment for $10 \mu \mathrm{M}$ culture for 6 hours); HFD + $\mathrm{HOCl}$ treatment group ( $\mathrm{HOCl}$ intervention for $100 \mu \mathrm{M}$ culture for one hour).

Statistical analysis

The data obtained from statistical processing were expressed as mean \pm standard deviation. The statistical processing was carried out using SPSS11.0 for Windows statistical software. One-way ANOVA (analysis of variance) was used to test the significance of mean difference between two samples in each group.

\section{Results and Discussion}

Analysis of the degree of atherosclerosis The plaque area of WT mice in the HFD group was compared with that of WT mice treated with EA for 14 weeks. The results showed that the plaque area decreased significantly after EA treatment in WT mice. In the $\mathrm{ApoE}^{-/-}$mice groups the EA treatment determined a slight decrease of the plaque area compared with the ApoE ${ }^{-/-}$HFD group but without reaching the statistical significance (Figure 1).

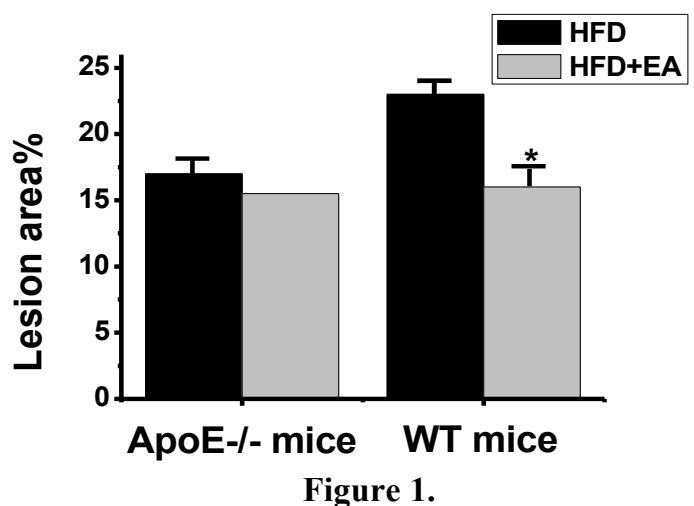

Comparison of plaque areas between $\mathrm{ApoE}^{-/-}$and WT HFD and HFD + EA groups $* \mathrm{p}<0.05$ compared with the WT - HFD group 


\section{Detection of blood biochemical indexes}

In the WT - HFD+EA group the association of EA to the HFD diet determine a significantly decrease in the level of TC and TG compared to WT-HFD group from $5.2 \pm 1.3 \mathrm{mmol} / \mathrm{L}$ and respectively $1.5 \pm 0.2$ $\mathrm{mmol} / \mathrm{L}$ in WT-HDF group to $4.0 \pm 0.9 \mathrm{mmol} / \mathrm{L}$ and respectively $1.1 \pm 0.2 \mathrm{mmol} / \mathrm{L}$ in $\mathrm{WT}-\mathrm{HFD}+\mathrm{EA}$ group $(p<0.05)$. Regarding the expression of cell adhesion molecules, EA treatment determined a significantly decrease of sICAM-1 and sP-selectin levels from $1182 \pm 102 \mathrm{ng} / \mathrm{mL}$ and respectively $55 \pm 11 \mathrm{ng} / \mathrm{mL}$ in WT-HFD group compared to $1005 \pm 74 \mathrm{ng} / \mathrm{mL}$ and respectively $36 \pm 9 \mathrm{ng} / \mathrm{mL}$ in WT-HFD+EA group $(\mathrm{p}<0.05)$. EA significantly increased the antioxidant activity evaluated by FRAP method: $501 \pm 36 \mu \mathrm{mol}$ $\mathrm{Fe} / \mathrm{L}$ in WT-HFD group to $525 \pm 38 \mu \mathrm{mol} \mathrm{Fe} / \mathrm{L}$ in WT-HFD+EA group $(\mathrm{p}<0.05)$. The same trend was also observed in the ApoE ${ }^{-/-}$-HFD groups where the levels of TC and TG decreased in the ApoE ${ }^{-/}$-HFD + EA group at $35 \pm 3.1 \mathrm{mmol} / \mathrm{L}$ and respectively $2.3 \pm$ $0.5 \mathrm{mmol} / \mathrm{L}$ compared to $47 \pm 3.8 \mathrm{mmol} / \mathrm{L}$ and respectively $3.6 \pm 0.7 \mathrm{mmol} / \mathrm{L}$ in $A$ poE ${ }^{-/-}$-HFD group. The sICAM-1 and sP-selectin levels significantly decreased after EA treatment in $\mathrm{ApoE}^{-/-}$-HFD + EA group at $868 \pm 57 \mathrm{ng} / \mathrm{mL}$ and respectively $59 \pm 4.4$ $\mathrm{ng} / \mathrm{mL}$ compared with $1163 \pm 69 \mathrm{ng} / \mathrm{mL}$ and respectively $71 \pm 9.2 \mathrm{ng} / \mathrm{mL}$ in $\mathrm{ApoE}^{-/-}$-HFD group $(\mathrm{p}<0.05)$. The FRAP level significantly increased in $\mathrm{ApoE}^{-/-}$-HFD + EA group to $456 \pm 32 \mu \mathrm{mol} \mathrm{Fe} / \mathrm{L}$ compared with only $391 \pm 18 \mu \mathrm{mol} \mathrm{Fe} / \mathrm{L}$ in $\mathrm{ApoE}^{-/-}$HFD group $(\mathrm{p}<0.05)$ (Figure 2).
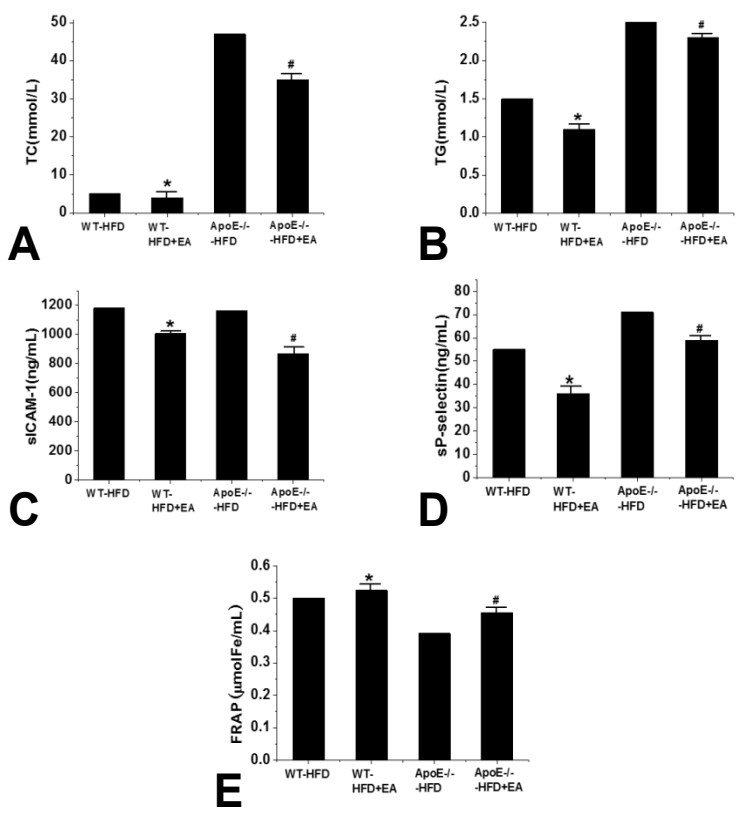

Figure 2.

Blood biochemical indexes in the studied group

A: TC of each group; B: TG of each group; C: sICAM-1 of each group; D: sP-selectin of each group; E: FRAP of each group ${ }^{*} \mathrm{p}<0.05$ compared with WT-HFD group; ${ }^{*} \mathrm{p}<0.05$ compared with $\mathrm{ApoE}^{-/}$-HFD group
Nitric oxide synthase (NOS) activity

Figure 3 shows that the activity of nitric oxide in mice fed with HFD is lower than that in mice fed with high-fat diet supplemented with ellagic acid, which is much higher than that of the former $(\mathrm{p}<0.05)$.

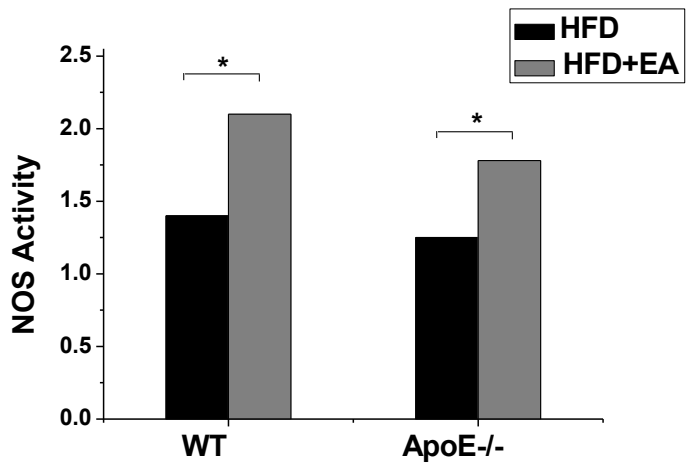

Figure 3.

Nitric oxide synthase activity in aorta $(* \mathrm{p}<0.05)$

Detection of $\mathrm{Nrf} 2$ and $\mathrm{HO}-\mathrm{I}$ expressions

The Western Blot analysis of the Nrf2 and HO-1 proteins in thoracic aorta tissues showed that their expression was significantly increased in both WT and $\mathrm{ApoE}^{-/-}$groups after EA treatment (Figure 4).

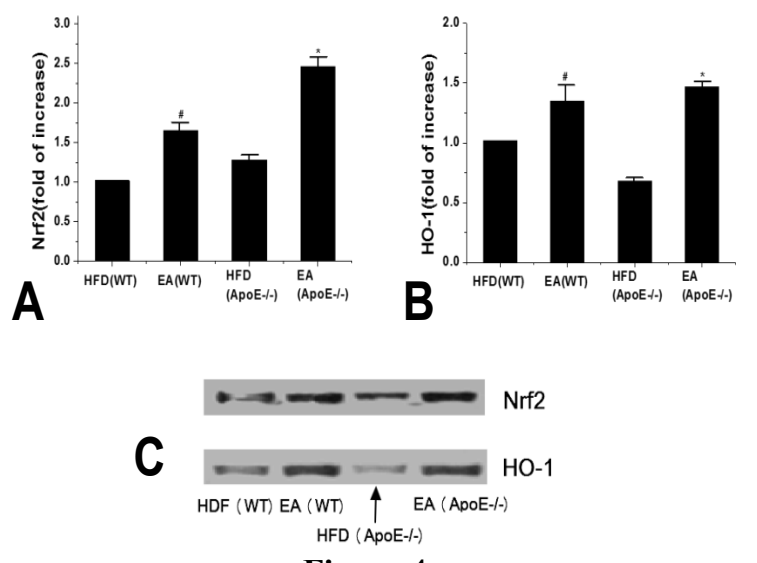

Figure 4.

Expression of Nrf2 and HO-1 proteins in the thoracic aorta of each group

A: Expression of Nrf2 protein in thoracic aortic tissue of each group; B: Expression of HO-1 protein in thoracic aortic tissue of each group; C: Electropherogram of Nrf2 and HO-1 protein. ${ }^{*} \mathrm{p}<0.05$ compared with WT-HFD group; ${ }^{*} \mathrm{p}<0.05$ compared with $\mathrm{ApoE}^{-/}$-HFD group.

\section{Detection of vasodilation functions in mice}

As shown in Figure 5 and compared with the $\mathrm{ApoE}^{-/-}$ mice in the HFD group, the vasodilation of mice in the EA intervention group was significantly improved. However, the vasodilation was not significantly improved in the group undergoing HOCl-induced oxidative damage, which triggered vascular endothelial dysfunction. In this experiment, the addition of EA significantly reduced the vasodilation of $\mathrm{HOCl}$. 

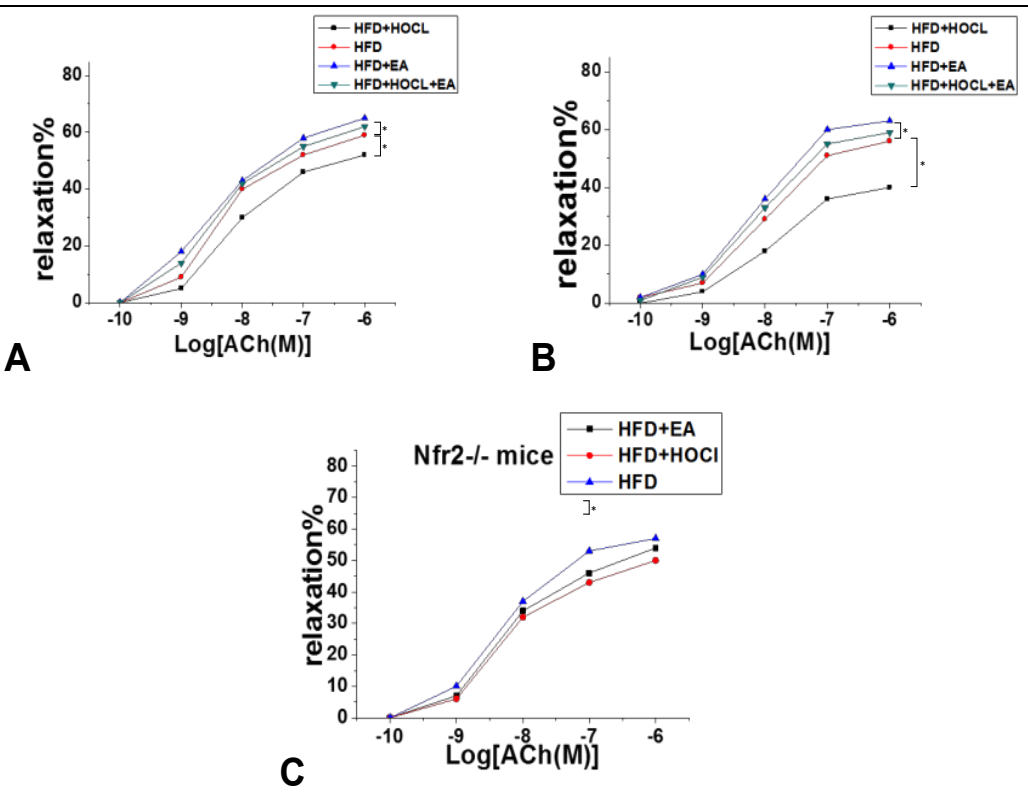

Figure 5.

Diastolic function of abdominal aortic rings in different treatment groups

(A: WT mice in HFD + HOCl, HFD, and HFD + EA groups; B: Diastolic function of ApoE ${ }^{-/}$mice in HFD + HOCl, HFD, and HFD + EA groups; C: Diastolic function of Nrf2 ${ }^{-/-}$mice in HFD + HOCl, HFD and HFD + EA groups) $* \mathrm{p}<0.05$.

The vascular rings of WT mice and $\mathrm{Nrf}^{-/-}$mice were pre-treated with $\mathrm{HOCl}$. The oxidative damage model was established as shown in Figure 3A-C. For the vascular rings of WT mice in normal culture, the oxidative damage caused by $\mathrm{HOCl}$ decreased significantly after $6 \mathrm{~h}$ of cultivation with EA. However, the protective function of EA was not observed in vascular rings collected from $\mathrm{Nrf}^{-/-}$mice.

In many studies, EA has a variety of biological activities and pharmacological effects, and has antioxidant, anticancer and mutagenic properties. In recent years, its role in vascular protection has gradually aroused the interest of researchers. Because of its large amount of phenolic hydroxyl groups, EA has strong reducibility and is an ideal antioxidant. Previous studies on antioxidant activity show that EA has the same free radical scavenging activity as salicin, a natural antioxidant, while EA can effectively scavenge hydroxyl radicals and nitrous oxide. Ellagic acid and all kinds of natural medicinal foods rich in ellagic acid can interfere with the process of AS, but the molecular mechanism of ellagic acid in antiatherosclerosis has not been deeply studied. It has been found that EA and various natural medicinal foods rich in EA can interfere with the process of atherosclerosis, yet the molecular mechanism under the anti-atherosclerosis role of EA has not been explored [15]. In this study, when the WT mice were fed with HFD and EA, EA played a significant role to prevent AS. However, the protective effect of EA was not significant in $\mathrm{ApoE}^{-/-}$mice. Therefore, it was speculated that the result may be attributed to the severity of atherosclerosis in $\mathrm{ApoE}^{-/-}$mice or the low dosage of EA given to $\mathrm{ApoE}^{-/-}$mice.
Endothelial dysfunction and cell damage induced by oxidative stress play an important role in the development of cardiovascular diseases. Vascular endothelial dysfunction and reduced nitric oxide levels are early features of atherosclerosis [16, 17]. Compared with the HFD model group, WT mice and $\mathrm{ApoE}^{-/-}$mice fed with both EA and the HFD diet showed significant improvement in their ability of vascular endothelial expansion, especially under $\mathrm{HOCl}-$ induced oxidative damage. In the $\mathrm{HOCl}$ oxidative injury pre-treatment group, vasodilation is inhibited. $\mathrm{HOCl}$ can induce the imbalance of vascular endothelial function, and EA can significantly alleviate the vascular injury of $\mathrm{HOCl}$ in this experiment. Previous studies have found that the induced $\mathrm{HO}-1$ expression can reduce the lesion area of atherosclerosis in $\mathrm{ApoE}^{-/-}$ mice $[18,19]$. HO-1 also plays an antioxidant role in $\mathrm{HOCl}$-induced arterial injury to alleviate vascular endothelial dysfunction. The oxidative damage of arteries also increases NOS activity, which can induce the expression of HO-1 [20]. In the model of $\mathrm{HOCl}$-induced oxidative damage, EA can reduce the damage to vascular endothelial function in WT mice, but it cannot protect the vascular endothelial tissues in Nrf2 knockout mice. This result further confirmed that $\mathrm{Nrf} 2$ is a key protein involved in the antioxidant effect of EA [21, 22]. By investigating the effect of EA on AS in mice, this study showed that EA exerted a protective effect against stroke and atherosclerosis in humans.

\section{Conclusions}

The long-term administration of EA can delay the onset of atherosclerosis in human body. Therefore, 
it is of practical significance for researchers to study the effects of EA on improving the diastolic function of isolated mouse blood vessels after epoxidation injury.

\section{Acknowledgement}

This work was supported by Medical Health Science and Technology Project of Zhejiang Provincial Health Commission (2019KY005).

\section{References}

1. Thakur G., Mitra A., Basak A., Sheet D., Characterization and scanning electron microscopic investigation of crosslinked freeze dried gelatin matrices for study of drug diffusivity and release kinetics. Micron, 2012; 43(2-3): 311-320.

2. Saracoglu E, Vuruskan E, Cekici Y, Kilic S, Ay H, Ergun U, Oxidative injury associated with stenting of asymptomatic carotid artery stenosis. Vasa, 2017; 46(4): 268-274.

3. Otilia AȚ, Țica O, Antal L, Hatos A, Popescu MI, Pantea Stoian A, Bratu OG, Găman MA, Pițuru SM, Diaconu CC, Modern oral anticoagulant treatment in patients with atrial fibrillation and heart failure: insights from the clinical practice. Farmacia, 2018; 66(6): 972-976.

4. Pereira A, Fernandes R, Crisostomo J, Seica RM, Sena CM, The Sulforaphane and pyridoxamine supplementation normalize endothelial dysfunction associated with type 2 diabetes. Sci Rep., 2017; 7(1): 14357.

5. Salimi A, Talatappe BS, Pourahmad J, Xylene Induces Oxidative Stress and Mitochondria Damage in Isolated Human Lymphocytes. Toxicol Res., 2017; 33(3): 233-238.

6. Costa C, Tsatsakis A, Mamoulakis C, Teodoro M, Briguglio G, Caruso E, Tsoukalas D, Margina D, Dardiotis E, Kouretas D, Fenga C, Current evidence on the effect of dietary polyphenols intake on chronic diseases. Food Chem Toxicol., 2017; 110: 286-299.

7. Fenga C, Costa C, Caruso E, Raffa L, Alibrando C, Gangemi S, Docea AO, Tsatsakis AM, Current evidence on the protective effect of dietary polyphenols on breast cancer. Farmacia. 2016; 64(1): 1-12.

8. Kouka P, Priftis A, Stagos D, Angelis A, Xinos N, Skaltsounis AL, Mamoulakis C, Tsatsakis AM, Spandidos DA, Kouretas D, Assessment of the antioxidant activity of an olive oil total polyphenolic fraction and hydroxytyrosol from a Greek Olea europea variety in endothelial cells and myoblasts. Int J Mol Med., 2017; 40(3): 703-712.

9. Sani TA, Mohammadpour E, Mohammadi A, Memariani T, Yazdi MV, Rezaee R, Calina D, Docea AO, Goumenou M, Etemad L, Shahsavand S, Cytotoxic and apoptogenic properties of dracocephalum kotschyi aerial part different fractions on calu- 6 and mehr- 80 lung cancer cell lines. Farmacia, 2017; 65(2): 189-199.

10. Velescu BŞ, Anuţa V, Aldea A, Jinga M, Cobeleschi PC, Zbârcea CE, Uivarosi V, Evaluation of protective effects of quercetin and vanadyl sulphate in alloxan induced diabetes model. Farmacia, 2017; 65(2): 200-206.

11. Firdaus F, Zafeer MF, Anis E, Ahmad M, Afzal M, Ellagic acid attenuates arsenic induced neuroinflammation and mitochondrial dysfunction associated apoptosis. Toxicol Rep., 2018; 5: 411-417.

12. Perez-Lahiguera F, Rodilla E, Costa JA, Pascual JM. Central blood pressure and vascular damage. Med Clin (Barc.), 2015; 145(2): 49-54.

13. Khavandi K, Aghamohammadzadeh R, Luckie M, Brownrigg J, Alam U, Khattar R, Malik RA, Heagerty AM, Greenstein AS, Abnormal Remodeling of Subcutaneous Small Arteries Is Associated With Early Diastolic Impairment in Metabolic Syndrome. $J$ Am Heart Assoc., 2017; 6(4): e004603.

14. Zhou Y, Guo HY, Pneg F, Effect of Shenmai injection on vascular endothelial dependence diastolic function in coronary heart disease patients. China Med Abstr (Int Med.), 2017; (02): 14.

15. Sharif H, Wainman L, O'Leary D, D Ditor, The effect of blood volume and volume loading on left ventricular diastolic function in individuals with spinal cord injury. Spinal Cord, 2017; 55(8): 753-758.

16. Sanders TL, Johnson NR, Levy NM, Effect of Vascular Injury on Functional Outcome in Knees with MultiLigament Injury: A Matched-Cohort Analysis. $J$ Bone Joint Surg-Amer., 2017; 99(18): 1565-1571.

17. Cappetta D, Angelis AD, Ciuffreda LP, Cole PAJ, Cardio-renal positive effects of dipeptidyl peptidase 4 inhibitor sitagliptin preserve diastolic function in a model of heart failure with preserved ejection fraction. Vasc Pharmacol., 2018; s103-105: 1565-1571.

18. Perek B, Kowalska K, Kempisty B, Nowicki A, Jankowski M, Nawrocki MJ, Malińska A, Role of macrophages in the pathogenesis of atherosclerosis and aortocoronary graft disease. J Biol Regul Homeost Agents, 2018; 32(5): 1055-1059.

19. Soni D, Wang DM, Regmi SC, Mittal M., Vogel SM, Tiruppathi C, Deubiquitinase function of A20 maintains and repairs endothelial barrier after lung vascular injury. Cell Death Discovery, 2018; 4(1): 60.

20. Tian L, Neuber-Hess M, Mewburn J, Kimberly D, Danchen DS, Hueih C, Zhigang WK, Willard WH, Sharp S, Kutty SL, Ischemia-induced Drp1 and Fis1mediated mitochondrial fission and right ventricular dysfunction in pulmonary hypertension. J Mol Med., 2017; 95(4): 381-393.

21. Suto M, Tanaka H, Mochizuki Y, Mukai J, Soga F, Sano H, Impact of overweight on left ventricular function in type 2 diabetes mellitus. Cardiovasc Diabetol., 2017; 16(1): 145.

22. Li Y, Zhu G, Paolocci N, Zhang P, Takahashi C, Okumus N, Murphy AM, Heart Failure-Related Hyperphosphorylation in the Cardiac Troponin I C Terminus Has Divergent Effects on Cardiac Function In Vivo. Circ Heart Fail, 2017; 10(9): e003850.

23. Liu Y, Li LN, Guo S, Zhao XY, Liu, YZ, Liang C, Gao L. Melatonin improves cardiac function in a mouse model of heart failure with preserved ejection fraction. Redox Biology, 2018; 18: 211-221. 